\title{
Competitive Capability of Some Typical Selected Veterinary Drug Manufacturers in Vietnam in the Context of International Economic Integration
}

\author{
Pham Dac Thang \\ Toan Thang Veterinary Drug Joint Stock Company
}

Received: Mar. 1, 2021 Accepted: Apr. 1, $2021 \quad$ Online published: Apr. 19, 2021

doi:10.5296/ijhrs.v11i2.18365ＵRL: https://doi.org/10.5296/ijhrs.v11i2.18365

\begin{abstract}
In the process of deeper and broader integration into the world and regional economy, Vietnamese businesses in general and veterinary drug manufacturers in particular have had advantages as well as disadvantages. Veterinary medicine manufacturers' advantages are, such as: market expansion, access to science and technology, access to capital, improving management skills, etc. Nevertheless, it also faces many challenges and risks. During the development phase, Vietnamese veterinary medicine manufacturers have to face robust competition from regional and international competitors. Besides, meeting industry standards (such as GMP) is also a prerequisite for veterinary drug manufacturers in Vietnam to focus on implementation. This study analyzes the competitiveness of Vietnamese veterinary drug manufacturers, on that basis gives discussions, thereby proposing some recommendations in order to enhance the competitiveness of Vietnamese veterinary medicine manufacturers in the context of international economic integration.
\end{abstract}

Keywords: competitive capability, enterprises manufacturing veterinary medicine, international economic integration

\section{Rationale}

In the context of international economic integration- creates a level playing field for all domestic and foreign businesses, Vietnamese businesses have many opportunities but also face many difficulties and challenges. One of the major challenges facing Vietnamese businesses is their competitiveness. FDI enterprises are free to do business and to invest as well as enjoy other benefits and preferences like domestic enterprises when doing business in Vietnam. Besides, FDI enterprises are enterprises with advantages in capital size, possessing modern advanced technologies, good management skills, large market, etc. Hence, competition will be a problem becoming fiercer for Vietnamese businesses. In particular, 
Vietnam and other countries in the world are in the process of industrial revolution 4.0, as a result, the competitive activities become more complicated and difficult. Therefore, in order to survive and develop, it is suggested that Vietnamese businesses need to focus on improving their competitiveness because it is the key to the success of all enterprises.

It is Vietnam that is known as an agricultural country with the orientation of producing and exporting livestock products to contribute to economic growth, reduce poverty, protect human health and ensure safety and hygiene food. The domestic veterinary industry was born with the mission of preventing and combating epidemics in livestock to create a safe food supply, protect the ecological environment and public health. Up to now, the veterinary medicine manufacturing industry has shown the role and importance of enterprises in the industry for the national economic development in general and the agricultural sector in particular. However, under the impact of the industrial revolution 4.0, it changes the entire production method, social organization, including humans in the interactions of the future, changing both the way of production and production arrangement. In fact, current production results have made domestic veterinary drug manufacturers become weaker in their specific competitive capability. In order to survive and thrive in an increasingly competitive environment, veterinary drug manufacturers need to make great efforts in building and improving their competitiveness compared to foregin enterprises. Nonetheless, these are not only normal competitive capability but also dynamic competitive competence, allowing businesses to adapt well to the competitive environment, creating conditions for enterprises to improve their competitive capability, business efficiency as well as sustainable development.

\section{Overview Researches on Competitive Capability of Enterprises}

Competitive capability of enterprises is a topic mentioned in many recent studies. According to Porter (1980), the competitiveness of enterprises is the firm's ability to maintain, expand market share and achieve high profits. This is a fairly common concept nowadays, according to which competitiveness is the ability to consume goods and services compared with competitors and the "profitability" of enterprises. In later studies, many authors have based on Porter's point of view to make arguments about their competitiveness, most of the studies emphasize the importance of enhancing competitiveness to with business. According to D'Cruz (1992), a firm with good competitiveness will outperform its competitors in many aspects (both price and quality). With this same point of view, Sanchez \& Heene (2004) said that improving the competitiveness of enterprises will create higher competitive advantages, productivity and quality than their competitors, occupy large market share, generate revenues, and sustainable development. Especially in the current international economic integration context, the volatility of the economy leads to the appearance of the perspective on dynamic capacity. Ambrosini \& Bowman (2009) argued that dynamism is built rather than buying and selling in the market. It includes components and develops over time. Dynamic competence emphasizes the continuous pursuit of reconfiguration, innovation and regeneration of core resources, capabilities and competencies to respond to environmental changes (Leonard, 1992). Collis (1994) argued that the dynamic competence is proportional to the change of abilities. It is the basis or principle to create competitive advantages and bring business efficiency to businesses. Therefore, dynamic capabilities will integrate resources as well as 
focus on the allocation of resources within the enterprises (Eisenhart \& Martin, 2000).

As a result, dynamic capacity can be understood as outstanding capabilities within an enterprise that are able to adapt well to environmental changes, helping businesses maintain their competitive advantage. Thus, in the conditions of fierce competition and unpredictable fluctuations of the business environment, the creation and maintenance of dynamic capacity are considered key factors to help businesses succeed and stand firmly in the market.

Referring to factors affecting the competitiveness of businesses in general, Ambastha and Momaya (2004) pointed out three groups of factors including: (1) Resources (human resources, structure, culture, technology, assets of the enterprise); (2) Process (strategy, management process, technology process, marketing process); (3) Performance (cost, price, market share, new product development). Along researching on this topic Ho (2005) studied the relationship between corporate governance activities and competitive capability. The author gives a model to measure governance activities in the enterprise through five aspects, (1) Board structure; (2) Management positions; (3) Leadership strategy; (4) Concentrated ownership and capital-market relationships; (5) Social responsibility having a relationship with the competitiveness of the business. Thompson, Strickland \& Gamble (2007) proposed factors affecting overall competitiveness of an enterprise based on 10 factors (Image / reputation, technology, distribution network, product development and innovation, production costs, customer service, human resources, financial status and advertising levels, change in management capabilities).

Later, Onar and Polat (2010) studied 104 listed companies at the Istabul Stock Exchange Turkey through interviewing the general manager or director of human resources based on the 7-point Likert questionnaire. This study has analyzed the factors affecting competitiveness of enterprises including (1) management ability, (2) production ability, (3) sales-marketing ability, (4) logistics logistics capabilities, (5) information technology, (6) finance - accounting, (7) human resources, (8) customer service, (9) supply, (10 ) research and development, (11) technology governance, (12) innovation and (13) customer relations. The results of this research show that the more correct the strategic decision, the more competitive it will be. For Vietnamese market, Bui Duc Tuan (2011) has evaluated the barrier factors affecting the competitiveness of the current Vietnamese seafood processing industry, in addition to a number of competitive advantages. They are certainly compared to other countries in the world such as: natural advantages, domestic demand, domestic competitive environment, etc. Hoang Nguyen Khai (2016) has developed indicators to evaluate the competitiveness of Specific commercial banks such as: Financial capacity; Competence of products and services; Banking technology level; Human resources and governance capacity; Market share and market share growth rate of commercial banks. Pham Thu Huong (2017) pointed out the factors affecting the competitiveness of enterprises including: (1) Enterprise management organization capacity; (2) Marketing capacity; (3) Financial capacity; (4) Technology innovation capacity; (5) Service organization capacity; (6) Market factors; (7) Institution and policy; (8) Infrastructure; (9) Supporting industries; (10) Qualification of human resources. 
Therefore, many previous researches on competition have been deepened into research for a long time with various views such as: (i) competitiveness based on resources; (ii) factors affecting the competitiveness of businesses; (iii) factors measuring the competitiveness of the business; (iv) enhancing the competitiveness of enterprises, etc. However, the previous approaches often put competitiveness in a stable and balanced environment, but there are not many researches regarding competitive capability in the context of a volatile and changing environment. Therefore, in recent year there are a number of studies on competitiveness in the condition of constant movement of environmental factors, also known as dynamic competitive capability. G.Gurkan Inan \& Umit S. Bititci (2015) illustrated organizational capacity and dynamics in the context of small-scale firms. This study has outlined 8 components of small-scale enterprise's dynamics including: connectivity capacity; capacity to identify business environment, creative capacity and product development; the capacity to copy and imitate; marketing and sales capabilities; ability to learn; reformatting and decision-making capacity. Meanwhile, Dinh Tho and Nguyen Thi Mai Trang (2009) on the basis of a synthesis of previous studies on dynamic capacity have given four factors that create dynamic capacity including: business orientation, learning orientation, marketing capacity and creative capacity. Nguyen Phuc Nguyen (2016) hypothesizes that there are five components that affect the dynamic competitiveness of Vietnam's tourism enterprises: absorption capacity (ability to absorb), ability to adapt, creativitve capability, connetive capacity, cognitive capacity, and market orientation.

It should be noted that the dynamic capability also depend a lot on the way they operate, in which differences in the performance of firms can be explained by the dependence on their use, setting up the resources according to the development (Zott, 2003; Bayer \& Gann, 2007; Ellonen et al., 2009). Consequently, each company is following specific ways of capacity building that are not the same as other companies and thus cause differences in performance results (Wang \& Ahmed, 2007).

\section{Current Situation of Competitive Capability of Vietnamese Veterinary Drug Manufacturers}

\subsection{Vietnamese Veterinary Drug Market}

The veterinary drug is seen as one of the industries that plays an important role in the socio-economic development strategy of Vietnam. Animals are raised for many nt purposes such as: raw materials for industrial processing, security and defense, pharmaceuticals, food, entertainment, etc. The diversity of livestock species is also potentially epidemic with different diseases. As a result, it is necessary to ask for the corresponding veterinary drugs. In fact, Veterinary medicine is an important factor in ensuring the health of animals. More than 20 years ago, it can be said that Vietnam has never had a free market for veterinary drugs. Since the country's renewal since 1986 up to now, it has brought about great achievements in many fields, including Vietnam's veterinary medicine industry.

With the demand for livestock development, the veterinary medicine industry in Vietnam has responded better and more fully in terms of quantity and quality. In the period 2015 - 2018, the total demand for veterinary drugs in our country tended to continuously increase. The 
total market value of Vietnam's veterinary drugs (including vaccines, chemicals, biological products, ...) used in livestock production increased from 3280 billion VND in 2015 to 3936 billion VND in 2018. The three main groups of livestock in our country which are poultry, pigs and cows, pigs are the species with the highest total veterinary drug demand. Statistically, the total demand for veterinary medicine for pigs has increased from 2140 billion VND in 2015 to 2568 billion VND in 2018.

Table 3.1. Total demand for veterinary drug in Vietnam from 2015 to 2018

\begin{tabular}{|l|r|r|r|r|}
\hline \multicolumn{1}{|c|}{ Content } & \multicolumn{1}{|c|}{$\mathbf{2 0 1 5}$} & $\mathbf{2 0 1 6}$ & \multicolumn{1}{c|}{$\mathbf{2 0 1 7}$} & \multicolumn{1}{c|}{$\mathbf{2 0 1 8}$} \\
\hline Poultry (billion VND) & 920 & 985 & 1048 & 1104 \\
\hline Pigs $($ billion $V N D)$ & 2140 & 2290 & 2439 & 2568 \\
\hline Cattle $($ billion $V N D)$ & 220 & 235 & 250 & 264 \\
\hline Total: (billion $V N D)$ & 3280 & 3510 & 3727 & 3936 \\
\hline
\end{tabular}

Source: http://nhachannuoi.vn/thuoc-thu-y-chuan-gmp-cuoc-dua-moi-chi-bat-dau/

Regarding the supply of veterinary drugs in Vietnam, there have been many steps forward to meet the increasing demand in the market. In 2016, Vietnam had 61 veterinary drug companies meeting the standards of drug manufacturing practice (GMP), with more than 11,000 veterinary drug products licensed for circulation (of which 4000 veterinary drug products were imported). Moreover, veterinary medicine from Vietnam has been exported to 40 countries with an average annual turnover of more than 20 million USD (source: http://nhachannuoi.vn/). In 2018, Vietnam had 72 veterinary drug companies meeting GMP standard. However, most of the veterinary drugs supplied on the market are foreign imported drugs. According to the Ministry of Agriculture and Rural Development, domestic enterprises account for about $20 \%$ of the market share, the remaining $80 \%$ of the market share is in the hands of multinational corporations (source:http://agro.gov.vn/)/

A major challenge facing veterinary medicine companies in Vietnam is the issue of ensuring industry standards . First of all, the production of veterinary drugs in our country must strictly comply with the GMP standard to ensure quality and healthy competition. The GMP standard is a measure of product quality that helps the livestock industry control epidemics, and simultaneously creates favorable conditions for veterinary drug manufacturers to develop, meeting domestic consumption and export demand. However, many Vietnamese enterprises are facing difficulties in applying this standard. In addition, Vietnam's veterinary medicine market is also a "fertile land" where illegal business activities, counterfeiting, and counterfeit products appear; together with the problem of antibiotic resistance in livestock appears. These are indeed big challenges for the veterinary medicine market of Vietnam.

\subsection{Vietnamese Veterinary Drug Manufactures}

Undoubtely, the demand for veterinary drugs in our country is huge that has created a premise for veterinary medicine companies' development. Veterinary drugs are used in many different stages of development of livestock, both in disease prevention and treatment, and in improving productivity and quality of livestock products. Along with the development of animal husbandry, the business of veterinary medicine is growing day by day. Many factories, 
shops sell veterinary drugs, and importing companies of veterinary drugs have been established and come into operation. Capturing the needs of the market, many Vietnamese veterinary drug prdocuing companies have been established in recent years.

Nonetheless, the production of veterinary drugs is a specific profession. It affects the environment and human health, and at the same time must comply with strict requirements to create veterinary medicine products with high quality. In fact, Vietnamese enterprises always aim to maximize profits so they can produce fast acting veterinary drugs such as high levels of antibiotics to sell goods without taking into account of its long-term consequences. The abuse of antibiotics has created a strain of resistant and even multi-resistant bacteria, which are harmful to the livestock industry - veterinary medicine and human medicine (Ngo Thi Tuyet, 2016). Hence, in 2011, the Ministry of Agriculture and Rural Development applied a new rule: Enterprises producing veterinary drugs that do not meet good manufacturing practice (GMP) standards will be closed and their business license will be withdrawn. From then to 2015, the number of enterprises decreased from 150 to about 50 due to failure to meet the GMP standards.

To remove difficulties for veterinary drug companies in meeting industry standards, Vietnam has had timely support policies. Currently, the Law on Veterinary Medicine is issued and will take effect from 1/7/2016, regulating the rights and obligations of establishments producing veterinary drugs. Accordingly, the manufacturing companies of veterinary drugs that have the certificate of sale of veterinary drugs in Vietnam have the right to produce veterinary drugs. In addition, the Ministry of Agriculture and Rural Development has supported businesses to build GMP factories, organized a direct GMP expert team to guide businesses, implement and remove difficult problems for businesses. Simultaneously, it also facilitates the registration of new products for circulation and the granting of export certificates for enterprises producing veterinary drugs that have met the GMP standards (Department of Animal Health, 2015). Thus, number of veterinary drugs company meeting GMP standards in Vietnam has increased to 72 companies in 2018 .

Table 3.2. Number of veterinary drug manufacturers in Vietnam in the period of $2013-2018$

\begin{tabular}{|l|l|r|r|r|r|r|r|r|r|}
\hline \multirow{2}{*}{ No } & Eco region & \multicolumn{2}{|c|}{ Foreign } & \multicolumn{2}{c|}{ Multinational } & \multicolumn{2}{c|}{ Domestic } & \multicolumn{2}{c|}{ Total } \\
\cline { 3 - 10 } & & $\mathbf{2 0 1 3}$ & $\mathbf{2 0 1 8}$ & $\mathbf{2 0 1 3}$ & $\mathbf{2 0 1 8}$ & $\mathbf{2 0 1 3}$ & $\mathbf{2 0 1 8}$ & $\mathbf{2 0 1 5}$ & $\mathbf{2 0 1 8}$ \\
\hline $\mathbf{1}$ & North & 1 & 2 & 0 & 1 & - & 27 & - & 30 \\
\hline $\mathbf{2}$ & Middle & 0 & 0 & 0 & 0 & 1 & 1 & - & 1 \\
\hline $\mathbf{3}$ & South & 8 & 10 & 3 & 3 & - & 28 & - & 41 \\
\hline \multicolumn{1}{|l}{ Total } & $\mathbf{9}$ & $\mathbf{1 2}$ & $\mathbf{3}$ & $\mathbf{4}$ & - & $\mathbf{5 6}$ & $\mathbf{6 1}$ & $\mathbf{7 2}$ \\
\hline
\end{tabular}

Source: Department of Animal Health - Ministry of Agriculture and Rural Development

In addition, Vietnamese veterinary medicine companies have to face with robust competition from foreign competitors. In the field of veterinary medicine, to obtain the GMP standard, most of the Vietnamese veterinary enterprises have to invest by themselves, each qualified factory has to spend 50 to 100 billion VND (15 years amortization). In which, most of these businesses have to borrow capital. With difficulties in capital, businesses have to narrow the scale of investment, so it is very difficult to build brands and market the market. Meanwhile, 
foreign veterinary medicine companies have more advantages in terms of investment capital, product promotion, in addition to the breeders' preference to use foreign products, creating a competitive advantage for imported goods. Futhermore, particularly in the field of research and production of vaccines in Vietnam, up to now, there are about 4 units producing vaccines. Nonetheless, if all the revenue from the vaccine production of these 4 units only account for less than $5 \%$ of the market share of vaccines in the market, the remaining $95 \%$ will belong to the importers". "This shows that Vietnam is heavily dependent on foreign vaccines and it is very expensive to import this item. With the current level, Vietnam can only produce inactivated vaccines (dead vaccines) and can replace imported goods" (source: m.gmp.com.vn).

Although Vietnamese veterinary medicine manufacturers account for a small market share, they still have competitive capability as a consequence of natural, soil and exercise conditions, as well as production custom of people. When an epidemic occurs, these businesses have the ability to respond more quickly and control the disease better, creating consumer confidence. However, due to lack of good production conditions and high level of market competition, Vietnamese veterinary drug manufacturers have yet to make a breakthrough in production, still mainly at medium and small scale. To meet the rapidly increasing demand for veterinary drugs, the network of manufacturers is determined to build veterinary drug factories meeting GMP standards, aiming to increase the quality of veterinary medicine production in the country. Some enterprises having the top turnover in the veterinary medicine market in Vietnam are Anova, Vemedim, Bio Pharmachemie, etc.

Table 3.3. Top 10 revenues of some veterinary drug manufacturers in Vietnam

\begin{tabular}{|l|l|r|r|r|}
\hline No. & \multicolumn{1}{|c|}{ Enterprise's name } & \multicolumn{1}{c|}{$\begin{array}{c}\text { Poultry } \\
\text { products } \\
\text { (billion } \\
\text { VND) }\end{array}$} & $\begin{array}{c}\text { Pig- related } \\
\text { products } \\
\text { (billion } \\
\text { VND) }\end{array}$ & $\begin{array}{c}\text { Total } \\
\text { (billion VND) }\end{array}$ \\
\hline 1 & Anova & 200 & 100 & 300 \\
\hline 2 & Vemedim & 150 & 200 & 500 \\
\hline 3 & Bio pharmachemie & 350 & 100 & 450 \\
\hline 4 & Bayer & 130 & 70 & 200 \\
\hline 5 & Virbac & 70 & 80 & 150 \\
\hline 6 & Anova Pharma & 100 & 50 & 150 \\
\hline 7 & Navetco & 80 & 70 & 150 \\
\hline 8 & Thú y xanh & 120 & 80 & 200 \\
\hline 9 & Toàn Thăng & 100 & 50 & 150 \\
\hline 10 & Mebipha & 80 & 70 & 150 \\
\hline 11 & Hoàng Kim & 110 & 40 & 150 \\
\hline
\end{tabular}

Source: The graduate student synthesized himself based on the companies' data

Despite some achievements in the development process, Vietnamese veterinary drug manufacturers still face many difficulties in financial capacity, research level as well as Management policy is not clear. These things significantly affect the development of the field of veterinary medicine production. Hence, it is necessary to have more specific analysis to improve the competitiveness of Vietnamese veterinary drug manufacturers, especially in the context of international economic integration posing many new opportunities and challenges. 
3.3 Assessment of Competitive Capability of Vietnamese Veterinary Drug Manufacturers in the Context of International Economic Integration

\subsubsection{Competitive Capability of a Number of Typical Selected Veterinary Drug Manufacturers in Vietnam}

\section{- National Veterinary Medicine Joint Stock Company I (Vinavetco)}

National Veterinary Medicine Joint Stock Company I (Vinavetco) was established in 1973, operating under the model of state-owned enterprises with the main function of manufacturing, trading and importing vaccines and veterinary drugs for the livestock industry in the country. Implementing the Government's policy on the equitization of state-owned enterprises, in 2000, Vinavetco changed its operating model to the form of a joint stock company. Up to now, the company has produced and traded over 100 kinds of high quality, and diversified products. From medicine to prevention and treatment, parasitic bleach, health tonic, weight stimulant to fertility regulators, parasiticides and fungicides. The special strength of the Vinavetco is that the antibiotic products, especially antibiotics for digestive and respiratory diseases, have been recognized by veterinarians, farm owners and breeders. The company had 10 products awarded with the Golden Cotton Awards: Anti CRD, Gentatylodex, Trisulfon-depot, Pneumotic, Vinacoc ACB, Spectilin, Chlotetradesol, Lincomycin, Coli-Vinavet. Two gold medal winners are: Kanatialin and Calci-fort. Currently the Company has 114 registered products and circulated in the domestic market including company logo and 30 patented trademark products.

After more than 20 years of establishment and development, Vinavetco has gradually affirmed its competitive position in the domestic market, its competitive capability is shown through a number of aspects as follows:

\section{Innovation capacity}

With the mission of making Vinavetco a leading prestigious brand in the domestic and international markets, the business develops on the basis of quality and public health is the core value throughout all activities of the business. The organization is constantly researching, testing and launching high-quality products, along with the smartest solutions for partners to increase productivity and health of pets around the world.

With a spirit of social responsibility combined with advanced biochemical knowledge, the company constantly innovates and researches to come up with new solutions to optimize treatment and nutrition. Actually, innovation is the driving force behind our strong growth to be recognized and affirmed as the industry leader in the future. With the enthusiasm and continuous effort, the enterprise always tries to research, explore and combine with the world's advanced technology solutions to produce products with formulas of international standard and create reputation in the domestic and world market.

Understanding the importance of technology in boosting up product quality, the company has invested in building a factory that meets GMP - WHO standards issued by the Department of Animal Health and the Ministry of Health. 
Vinavetco factory is equipped with a modern laboratory system meeting GLP - WHO standards, a GSP - WHO standard goods storage system, advanced equipment system along with a team of experts, staff, management seasoned with experience and high expertise. In addition, all manufacturing processes are strictly tested under a closed system to ensure quality standards.

\section{Business-oriented competence}

From the very first stage of establishment, the scale was small and faced many difficulties in the context of a nascent business industry. Vinavetco has built its goal of becoming a typical enterprise and having a leading competitive position in the veterinary medicine industry through the main actions: (i) Improving product quality, considering quality Product quantity is the social responsibility that is decisive for the existence and development of the company and (ii) Proper investment in human resource development, human factor is considered the most important factor that determines the success or failure of the company. Starting from the import of vaccines and some veterinary pharmaceutical products, the enterprise has boldly invested in modern production lines, equipment systems and large-scale laboratories, achieving international standards. It has gradually mastered the technology and the products manufactured by the company are always highly appreciated by customers and partners.

In the development trend of a series of new products, substitute products. Vinavetco is also a pioneer in proactively receiving, taking short steps to catch up with new trends in product consumption, thereby redirecting business activities to best meet the needs of customers in the domestic market as well as export.

\section{Marrketing capability}

"For public health" is one of the core values that Vinavetco has built and implemented from the very first days of its establishment. With the enterprise's product awareness that plays a crucial role in the development of the livestock industry in general and is also a prerequisite for the quality and safety of food products in particular. Therefore, the company produces and sells a wide variety of high quality, and diversified products for animals, pets, domestic animals, domestic animals for disease prevention, parasitic bleach, health tonics, weight gain stimulants to drugs that regulate reproduction and kill mold. To ensure the development of business activities, the company annually reviews, consolidates and builds a new customer system, evaluates and adjusts the standards of tier-1 agents in the provinces, cities in the country. It also deployed marketing and sales activities through many channels: online, wholesale and retail agents, company stores, and constantly maintained good customer care. The firm established a team of technicians to technical support and consultancy for farms and breeders. On the other hand, training and professional training on how to use products for the system of salespeople and market staff of the business are also specially focused.

With those efforts, Vinavetco has achieved some key business results as follows: 
Table 3.4. Some operating results of Vinavetco in the period from 2014 to 2018

\begin{tabular}{|l|r|r|r|r|r|}
\hline \multicolumn{1}{|c|}{ Targets } & \multicolumn{1}{c|}{$\mathbf{2 0 1 4}$} & \multicolumn{1}{c|}{$\mathbf{2 0 1 5}$} & \multicolumn{1}{c|}{$\mathbf{2 0 1 6}$} & \multicolumn{1}{c|}{$\mathbf{2 0 1 7}$} & \multicolumn{1}{c|}{$\mathbf{2 0 1 8}$} \\
\hline Revenues (million VNĐ) & 268.006 & 236.715 & 260.108 & 176.325 & 149.161 \\
\hline Profit (million VNĐ) & 20.915 & 1.245 & -24.692 & -42.455 & -15.905 \\
\hline ROS (\%) & 7.80 & 0.53 & -9.49 & -24.08 & -10.66 \\
\hline ROA (\%) & 24,34 & 2,76 & $-32,56$ & 458,94 & 18,09 \\
\hline ROE $(\%)$ & 6,82 & 0,74 & $-7,58$ & $-17,59$ & $-9,22$ \\
\hline
\end{tabular}

Source: Author's calculation based on the enterprise's financial statements

\section{- Navetco Central Veterinary Medicine Joint Stock Company}

Navetco Central Veterinary Medicine Joint Stock Company is a state-owned enterprise established in 1955. It is a long-standing unit with more than 60 years of establishment and development, experiencing many historic political berths. As a leading unit in the field of vaccine production, the company standardizes, treats diseases, produces and trades all kinds of veterinary drugs. With the parallel development in both science and economy, the Company's products are always of high quality, meeting the demand for product quantity and quality, creating a reputation in both domestic and foreign markets, which worths the motto: "Navetco - A powerful assistant of breeders"

\section{Innovative and creative capability}

Navetco has a Research Center established by MARD, with the task of researching diseases of livestock and poultry and developing vaccines and veterinary medicine for use in disease prevention. The Center has successfully implemented many projects at the national, ministerial and grassroots levels related to dangerous diseases in cattle. In addition, the company's Board of Directors also pays attetion to promoting scientific research associated with production, implementing scientific research projects according to the requirements of reality, focusing on researching new products which are proactive, highly competitive and welcomed by the market as high-quality pharmaceutical products and biotechnology-applied goods. Indeed, successes in research are of great significance, not only making scientific contributions to the veterinary industry, but also playing an important role in the development and stability of the Company.

\section{Cooperarive capacity}

Research cooperation is also a strength of the Company. Many joint research projects between the Navetco Company and the University of Queensland, the Australian Animal Health Laboratory (AAHL) funded by ACIAR or the CARD Program funded by AUSAID are evaluated for success in terms of the scientific and economic aspects, including the research project on pig and poultry septicemia; project to produce heat-resistant Newcaslte vaccines; The Duck Cholera Cellular Disease Project and the Duck Cholera Cellular Vaccine, 
and the recent success of a Swine Swine Cell Vaccine project. There is no doubt that research cooperation with domestic organizations brings in many successes, especially the research project with the Institute of Biotechnology on $\mathrm{H} 5 \mathrm{~N} 1$ avian influenza vaccine and Interferon production with NANOGEN company.

\section{Marketing capability}

Especially in 2012, the Company successfully produced avian influenza vaccine NAVET-VIFLUVAC. This is the pride of the Company and the Veterinary Industry of Vietnam when our country produces influenza vaccine for the first time, contributing to economic efficiency and more importantly, proactively in the prevention of avian influenza. Regarding pharmaceutical production, up to now, the Company has produced 123 veterinary pharmaceutical products and aquatic veterinary medicine, including vitamins, micronutrients, probiotics and pain relievers - antipyretic, anti-inflammatory - hormonal, antiparasitic, antibiotic and antiseptic treatment, meeting the needs of domestic farmers and regional markets.

All products of the Company are manufactured on modern technology lines meeting GMP-WHO standards certified by Department of Animal Health - Ministry of Agriculture and Rural Development and Bureau Veritas Certification (BVC) in 2013; the production process strictly complies with the quality management system ISO 9001: 2008 of BVC. The company's products are not only widely used by breeders for disease prevention and treatment, but some products are also selected by the Ministry of Agriculture and Rural Development to serve for the national reserve.

With the strength of technology, a highly skilled and experienced workforce, the company's products always create a reputation in the domestic and foreign markets. Currently the goods manufactured by the company have been sold in all 63 provinces and cities nationwide and are available in some countries in the region such as Cambodia, Laos, Myammar, Bangladesh, China, and so on. Successfully, revenues in the following years are always higher than the previous year.

In addition to trading the products produced by the Company, Navetco also imports some high quality products that it has not yet produced from France, the Netherlands, the Russian Federation, Japan, China, etc, in order to effectively serve the epidemic prevention work such as: foot and mouth vaccine, PRRS vaccine, SWIVAC C vaccine.

\section{Business- oriented competence}

Medicine Joint Stock Company commits:

(i) Apply, maintain and continuously improve the quality management system according to international standards ISO 9001 and GMP-WHO.

(ii) Equipped with modern machinery systems, technological lines, constantly improving the quality of human resources to meet the requirements of the GMP-WHO standards as well as the increasing requirements of customers. 
(iii) Strictly check the whole process from the beginning to the end to ensure the products are safe and effective for the breeders and meet the quality standards.

(iv) Always listen and promptly respond to customer requirements, constantly improve quality and diversify products to expand and meet market demands.

(v) This quality policy is disseminated to all employees of the company, ensuring that all employees understand and comply with actual operations.

\section{Learning capability}

In reality, Navetco defines human resources as a valuable asset, and is the decisive factor for the success and sustainable development of the company, based on those strategic goals. Moreover, the company plans to actively seek qualified resources, creative, and professional human resources. The development of human resources is oriented on the basis of prioritizing competencies, qualifications, experience and being regularly trained.

Table 3.5. Some operating results of Vinavetco in the period from 2014 to 2018

\begin{tabular}{|l|r|r|r|r|r|}
\hline \multicolumn{1}{|c|}{ Targets } & \multicolumn{1}{c|}{$\mathbf{2 0 1 4}$} & \multicolumn{1}{c|}{$\mathbf{2 0 1 5}$} & \multicolumn{1}{c|}{$\mathbf{2 0 1 6}$} & \multicolumn{1}{c|}{$\mathbf{2 0 1 7}$} & \multicolumn{1}{c|}{$\mathbf{2 0 1 8}$} \\
\hline Revenues (million VNĐ) & 623.652 & 662.958 & 713.290 & 788.998 & 868.885 \\
\hline Profits (million VNĐ) & 34.445 & 39.255 & 48.087 & 68.604 & 121.245 \\
\hline ROS (\%) & 5,52 & 5,92 & 6,74 & 8,70 & 13,95 \\
\hline ROA (\%) & 19,77 & 19,88 & 20,84 & 25,93 & 40,36 \\
\hline ROE (\%) & 6,68 & 5,92 & 5,31 & 6,68 & 11,52 \\
\hline
\end{tabular}

Source: Author's calculation based on the enterprise's financial statements

\section{General Appraisal}

From the analysis of the current status of Vietnamese veterinary drug manufacturers' competitive capability, the following conclusions can be made:

\subsection{Discussion}

Most of the Vietnamese veterinary drug manufacturers are aware of the importance of enhancing their competitiveness in the domestic and foreign markets. Two major Vietnamese veterinary medicine manufacturers, Navetco and Vinavetco, are the two pioneers in enhancing domestic and foreign competitiveness. Following the achievements of a number of leading enterprises, the remaining enterprises in the field of veterinary medicine production in Vietnam are constantly making efforts to innovate and create; apply advanced science and technology in the process of manufacturing and distributing veterinary drugs up to high standards; further improve learning capacity, cooperation capacity, marketing capacity, business-oriented capacity in recent years.

In order to create conditions for Vietnamese veterinary medicine manufacturers to improve 
their competitiveness, state management agencies have issued many policies to support and stimulate enterprises to apply advanced science and technology for upgrading the quality of veterinary medicine products. Furthermore, many trade promotion policies have been carried out in order to create conditions for Vietnamese veterinary drug manufacturers to improve their competitiveness in recent years.

\subsection{Limitations and Reasons}

In terms of innovation capacity: Business leaders' attention to innovation activities has not been adequate, leading to low investment efficiency in innovation activities. In addition, the creative capacity of the human resources as well as the ability to capture and process information in innovation activities have not met the requirements of the innovation process and not met the market demand leading to limited competitiveness.

Regarding learning orientation: The business has not really created a working environment in which members commit to increase learning for boosting up their work efficiency. Actually, enterprises have not clearly defined the learning objectives of their business in order to create knowledge advantages for enterprises and thereby increase other competitive capabilities of enterprises.

In respect to Marketing capacity: Marketing capacity still has many limitations in terms of ability to meet the diverse needs and tastes of customers, as well as the ability to respond to competitors' strategies. There is no market research department nor the services of a market research company to capture customers' needs, build long-term strategies, and make a difference to improve competitive capability on products, prices, distribution and promotion mix.

In terms of business-oriented capacity: Enterprises have not yet promoted business orientation from managers in the process of forming short- and long-term business strategies. Business orientation of the enterprises has not effectively supported other dynamic factors such as marketing, creative capacity and learning orientation. The process of developing orientations and strategies is not really clear, has not taken advantage of market opportunities and limited risks, and has not really come up with solutions to proactively respond to negative impacts from the market and business environment side.

On the subject of cooperation capacity: Most of the enterprises producing veterinary drugs in our country today are still mainly small and medium, and the capacity to cooperate among enterprises is still weak. In fact, enterprises have not actively identified the target market for their brands, and the assessment of the competitiveness of enterprises and competitors has not been done regularly and effectively.

\section{Suggestions}

As regards of innovative capacity: Innovation requires the attention of business leaders, the creative capacity of the team, the ability to capture and process information, and effective investment in innovation and creation.

First of all, for business leaders, it is necessary to be consistent with the goal of innovation in 
business operations, identifying the importance of innovation in its corporate development strategy; establishing rules and developing creative execution capacities for the workforce; equipping with methods and tools for creative thinking and new skills, training and implementing new business methods. In addition, it is necessary to create conditions for the workforce to boldly propose initiatives, respect and support the implementation of effective initiatives. Actually, innovative behaviors are stimulated and fully equipped with knowledge, skills, creating an innovation atmosphere in order to promote the capacity of innovation in enterprises. Especially for veterinary medicine manufacturing enterprises, it is required that labor skills must be active in research and development in order to improve the quality to meet the increasing and changing requirements of the market.

In terms of learning orientation: In reality, implementing the learning orientation of the business will contribute to creating knowledge advantages for businesses and thereby increasing other competitiveness of businesses.

Enterprises need to create a business environment in which members are committed to learning to increase their productivity. Learning in business should be seen as an investment, not a cost to the business. This is certainly the key to business survival, creating value and competitive advantages for businesses. As a result, it is necessary to create a commitment to always improve the spirit of learning in enterprises. They need to be open in learning, must always be reassessed and willing to receive feedback on opinions from other members. Along with that, businesses need to share their visions and development orientation for all members of their businesses in order to achieve a high consensus on the company's goals and direction. They must consider all members as partners to lead their businesses to achieve their set goals.

Marketing competencies: Successful products have to meet the biggest demands of the market, which requires effective marketing capabilities and appropriate distribution methods. On that basis, a number of issues thatbusinesses need to do as follows:

Enhancing ability to respond to customers through understanding their needs and desires and competitor's ability to respond to actions. Enterprises can use the services of market research companies or carry out by themselves. Regardless of which option, enterprises need to grasp some necessary knowledge and skills about market research to identify pros and cons, and market fluctuations in order to collect and use. Utilizing information that is necessary and useful for business decision-making related to customers and competitors. It is important to pay attention to the trustworthiness in the information conveyed to customers to avoid the unfortunate hype or misunderstanding that can destroy the brand. Currently, the green marketing trend is mentioned a lot with the message of green products addressed to customers. Indeed, veterinary drug manufacturers need to comply with the prescribed production standards, and need to provide clear information for customers to understand the environmental protection features of the products and the benefits that the products bring to outperform other products and emphasize the best ability to satisfy customers' needs.

Businesses need to realize that improving marketing capabilities is an opportunity to achieve their goals. By using effective marketing, especially green markting today, businesses can both approach customers and demonstrate their social responsibility to the community, 
thereby enhancing the reputation and image of yourself with consumers. It is necessary to regularly collect macro-environment information in order to be able to monitor changes in the macro-environment and adapt to such changes, especially in the current volatile veterinary medicine sector from now on. This work is assessed to be done more easily and less expensive because information about the macro environment is often included in the form of secondary data, widely available on mass media, specialized magazines, Internet, etc.

\section{Business-oriented competence}

The role of business orientation for an enterprise is very large because it increases other motivational factors such as marketing, creative capacity and learning orientation. It also raises businesses' expectations for the opportunity brought in by Vietnam's comprehensive integration. Therefore, in order to increase competitiveness, enterprises need to pay attention to the role of business orientation. They are suggested to focus on finding, recruiting and training high business-oriented entrepreneurs. They always need to be consistent and pioneer in entering the market with new products / services ahead competitors. They should also develop specific directions and strategies when participating in risky business projects with high opportunities for profitability and accepting market challenges to obtain business goals.

\section{On the subject of cooperation capacity}

The trend of cooperation is increasingly paid attention many businesses, including enterprises producing veterinary drugs. Since most of the enterprises that manufacture veterinary drugs in our country are still ubder mainly small and medium scale, enhancing the capacity to cooperate in cooperation is an indispensable need for these enterprises. In the context of rapidly developing globalization, Vietnam is deeply integrating with the international economy. This is both an opportunity and a great challenge for businesses in all sectors, including the animal husbandry and veterinary industry of our country. In order to improve cooperation capacity, veterinary drug manufacturers need to proactively define target markets for their brands, assess their competitiveness and that of their competitors so that various proposed ways can be available to promote their strengths. Indeed, this job requires enterprises to equip themselves with knowledge, skills, technology as well as orienting partners to cooperate effectively.

\section{References}

Ambastha, A., \& Momaya, K. (2004). Competitiveness of Firms: Review of Theory, Frameworks, and Models. Singapore Management Review, 26(1), 45-61.

Ambrosini, V., \& Bowman. C. (2009). What Are Dynamic Capabilities and Are They a Useful Construct in Strategic Management?. International Journal of Management Reviews. 11(1), 29-49. https://doi.org/10.1111/j.1468-2370.2008.00251.x

Bayer, S., \& Gann, D. (2007). Innovation and the dynamics of capabiliti accumulation in project-based firms. Innovation: Management, Policy \& Pratice, 9, 217-234. https://doi.org/10.5172/impp.2007.9.3-4.217 


\section{Macrothink}

International Journal of Human Resource Studies ISSN 2162-3058 2021, Vol. 11, No. 2

Bui, D. T. (2011). Improving the competitiveness of Vietnam's seafood processing industry [PhD thesis, National Economics University].

Cevik, S., \& Polat, S. (2010). The factors affecting the relationship between strategic options and the competence building process: An emprial examination. Research in competence Based Management, 5, 59-77. https://doi.org/10.1108/S1744-2117(2010)0000005006

D’Cruz, J. (1992). New Compacts for Canadian Competitiveness. DIANE Publishing.

David, J. C. (1994). Research Note: How Valuable Are Organizational Capabilities?. Strategic Management Journal, 15(S1), 143-152. https://doi.org/10.1002/smj.4250150910

Eisenhardt, K. M., \& Martin, J. A. (2000). Dynamic Capabilities What Are They?. Strategic Management Journal, 21 ,

$1105-1121$. https://doi.org/10.1002/1097-0266(200010/11)21:10/11<1105::AID-SMJ133>3.0.CO;2-E

Ellonen, H. K., Wikstrom, P., Jantunen, A. (2009). Linking dynamic-capability portfolios and innovation outcomes. Technovation, 29(11), 753-762. https://doi.org/10.1016/j.technovation.2009.04.005

Ho, C. K. (2005). Corporate Governance and Corporate Competitiveness: an international analysis. Corporate Governance An International Review, 13(2), 211-253. https://doi.org/10.1111/j.1467-8683.2005.00419.x

Hoang, N. K. (2016). Improving competitiveness of Vietnamese commercial banks, $[\mathrm{PhD}$ thesis, University of Commerce].

Inan, G. G., \& Bititci, U. S. (2015). Understanding Organizational Capabilities and Dynamic Capabilities in the Context of Micro Enterprises: A Research Agenda. Procedia - Social and Behavioral Sciences, 210, 310-319. https://doi.org/10.1016/j.sbspro.2015.11.371

Leonard, D. S., Bowman, V. D., Ready, D. F., Pak, W. L. (1992). Degeneration of photoreceptors in rhodopsin mutants of Drosophila. J. Neurobiol, 23(6), 605--626. https://doi.org/10.1002/neu.480230602

Ministry of Agriculture and Rural Development of Vietnam. (2011). http://agro.gov.vn/vn/tID22549_Doanh-nghiep-thuoc-thu-y-gap-kho-ve-von.html

Navetco Central Veterinary Medicine Joint Stock Company. (2018). Naveco Financial Statements

Ngo, T. T. (2016). Trading in veterinary drugs under the Veterinary Law 2015 [Master Thesis, Academy of Social Sciences, Vietnam Academy of Social Sciences].

Nguyen, H. (2017). GMP standard veterinary medicine: The race is just getting started. http://nhachannuoi.vn/thuoc-thu-y-chuan-gmp-cuoc-dua-moi-chi-bat-dau/

Nguyen. D. T., \& Nguyen, T. M. T. (2009). A number of factors that create business dynamics and solutions to nurture. Dynamic competitiveness of the business. Ho Chi Minh City. 


\section{Macrothink}

International Journal of Human Resource Studies

ISSN 2162-3058 2021, Vol. 11, No. 2

Nguyen. P. N. (2016). Enhancing dynamic competitiveness of businesses: Research in the tourism field. Journal of Economy \& Development, 225(2), 99-107

Pham, T. H. (2017), Competitiveness of SMEs, research in Hanoi city [PhD thesis, University of Mining]. Geology

Porter, M. E. (1980). Competitive Strategy: Techniques for Analyzing Industries and Competitors, New York: Simon and Schuster.

Sanchez, R., \& Heene, A. (1996). Strategic Learning and Knowledge Management. West Sussex, England: John Wiley \& Sons Ltd.

Thanhnien.com. (2015). Vietnamese veterinary medicine market- Delicious piece for peope. http://www.m.gmp.com.vn/thi-truong-thuoc-thu-y-viet-mieng-ngon-nhuong-nguoi.htm

Thompson, Jr., A., Strickland III, A. J., \& Gamble, J. E. (2007). Crafting \& Executing Strategy (15th ed.). New York: McGraw-Hill Irwin

Vietnam Department of Animal Health (2015), Report on the management of veterinary drugs.

Vinavetco. (2018). Vinavetco financial statements.

Wang, C. L., \& Ahmed, P. K. (2007) Dynamic Capabilities: A Review and Research Agenda. International Journal of Management Reviews, 9, 31-51. https://doi.org/10.1111/j.1468-2370.2007.00201.x

Zott, C. (2003). Dynamic Capabilities and the Emergence of Intraindustry Differential Firm Performance: Insights from a Simulation Study. Strategic Management Journal, 24, 97-125. http://dx.doi.org/10.1002/smj.288

\section{Copyright Disclaimer}

Copyright for this article is retained by the author(s), with first publication rights granted to the journal.

This is an open-access article distributed under the terms and conditions of the Creative Commons Attribution license (http://creativecommons.org/licenses/by/4.0/). 